\title{
Autoantibody-negative insulin-dependent Diabetes after COVID-19
}

\author{
Tim Hollstein \\ University of Kiel \\ Juliane Schulz \\ University of Kiel \\ Andreas Glück \\ University of Kiel \\ Dominik M Schulte \\ University of Kiel \\ Stefan Schreiber \\ University of Kiel \\ Stefan R Bornstein \\ University of Dresden \\ Matthias Laudes ( $\square$ matthias.laudes@uksh.de) \\ University of Kiel
}

\section{Short Report}

Keywords: type 1 diabetes, COVID-19

Posted Date: July 2nd, 2020

DOI: https://doi.org/10.21203/rs.3.rs-39343/v1

License: (c) (1) This work is licensed under a Creative Commons Attribution 4.0 International License.

Read Full License 


\section{Abstract}

Here we report the manifestation of insulin dependent diabetes after a COVID-19 infection in the absence of typical autoantibodies for type 1 diabetes. A 19-year-old Caucasian male subject presented to our emergency department with diabetic ketoacidosis (DKA). C-peptide levels accounted to $0.62 \mu \mathrm{g} / \mathrm{L}$ in the presence of blood glucose concentrations of $30.6 \mathrm{mmol} / \mathrm{L}(552 \mathrm{mg} / \mathrm{dL})$. The patient's case history revealed a COVID-19 disease 6-8 weeks prior to admission. This is of interest, since COVID-19 internalization into host cells is mediated via Angiotensin-converting enzyme 2 (ACE2) ${ }^{[1]}$, a transmembrane glycoprotein which amongst others is crucial for $\beta$-cell homeostasis and function $[2,3,4]$. Detailed laboratory testing was performed, revealing no serum-antibodies against islet-cells (ICA), glutamic acid decarboxylase (GAD65-AA), tyrosine phosphatase (IA-2-AA), insulin (IAA) and zinctransport-8 (ZnT8-AA), but against COVID-19. Hence, this is a presentation of an insulin-dependent diabetes mellitus in the absence of markers of autoimmunity, which might suggest direct cytolytic effects of COVID-19 on pancreatic $\beta$-cells presumably mediated via ACE2.

\section{Introduction}

The recent COVID-19 (Sars-CoV-2) pandemic represents a worldwide health crisis causing severe illness and death especially in subjects with cardiovascular and metabolic abnormalities ${ }^{[5,6]}$. Interestingly, it has been shown that COVID-19 enters human cells via Angiotensin-converting-enzyme 2 (ACE2), a transmembrane glycoprotein with proteolytic activity also found in pancreatic $\beta$-cells ${ }^{[1,2,3,4]}$. Therefore, we have recommended a careful management of patients with diabetes and to monitor for new onset diabetes during the pandemic ${ }^{[7]}$. Indeed, patients were reported in Asia with acute diabetic ketoacidosis associated with COVID-19 disease ${ }^{[8]}$.The exact time course, causal relationship and presence or absence of autoantibodies was however not provided.

\section{Case Presentation}

Here we present a 19-year-old Caucasian male subject submitted to our emergency department with abnormal fatigue, exhaustion, and $12 \mathrm{~kg}$ weight loss within several weeks. He exhibited increased polydipsia of approx. 6 liter per day, nycturia (2-3x per night), and an intermittent postprandial left-sided flank pain. No fever episodes and no typical chest pain were reported. Laboratory testing in our emergency department revealed a DKA with a blood pH of 7.1, a blood glucose concentration of 30.6 $\mathrm{mmol} / \mathrm{L}(552 \mathrm{mg} / \mathrm{dL}$ ), reduced serum C-peptide levels of $0.62 \mu \mathrm{g} / \mathrm{L}$ (normal range: $1.1-4.4$ ), a hemoglobin A1c of $16,8 \%$, as well as positive urinary ketones and glucosuria. Type 1 diabetes was assumed. The family history revealed a maternal cousin with type 1 diabetes and a maternal grandmother with type 2 diabetes. However, the immunological examination yielded absence of serumautoantibodies against islet-cells (ICA), glutamic acid decarboxylase (GAD65), tyrosine phosphatase (IA2), insulin (IAA) and zinc-transport-8 (ZnT8) in the affected patient (Tab. 1). The patient further reported 
that he had an asymptomatic COVID-19 (Sars-CoV-2) infection 6-8 weeks before when returning from vacations in Austria with his family. On April 29 $9^{\text {th }}$ 2020, he was tested positive for COVID-19 (Sars-CoV-2) IgG but not IgM indicating a previous COVID-19 infection.

The patient needed treatment on the intensive care unit for 3 days for re-compensating DKA using intravenous insulin therapy according to international guidelines. At day 4 , he was transferred to the endocrine ward and subcutaneous insulin therapy was initiated. In the course of the next days, blood glucose levels stabilized to 8.4 to $10.2 \mathrm{mmol} / \mathrm{L}$ (151 to $183 \mathrm{mg} / \mathrm{dL}$ ). The patient received an educational program according to guidelines for type 1 diabetes management. He was discharged from hospital in good condition after 10 days.

\section{Discussion}

It is known for several years that corona like viruses enter human cells via binding to membrane bound proteases $^{[1]}$. For example, the Middle East Respiratory Syndrome virus (MERS-CoV), responsible for an outbreak of acute respiratory syndrome, has been shown to use dipeptidylpeptidase (DPP4)-4, a protease known to be involved in the regulation of the incretin system ${ }^{[9]}$. Recently, it has been demonstrated in a functional assay, that ACE2 acts as the major binding partner for COVID-19 (Sars-CoV-2) spike glycoprotein mediating host cell internalization ${ }^{[10]}$.

ACE2 is widely expressed in eukaryotic cells membranes including those of pancreatic $\beta$-cells ${ }^{[2]}$. Using a high-fat diet mouse model it has been shown that $\beta$-cell dedifferentiation is accompanied by ACE2 reduction ${ }^{22}$. ACE2 deletion in NOD mice resulted in hyperglycemia, decreased $\beta$-cell insulin content and increased $\beta$-cell oxidative stress ${ }^{[3]}$. In addition, ACE2 deficiency reduced $\beta$-cell mass and impairs $\beta$-cell proliferation in obese $\mathrm{C} 57 \mathrm{BL} / 6$ mice ${ }^{[4]}$, overall suggesting this glycoprotein to be important for $\beta$-cell homeostasis. Finally, it is currently under debate, that ACE2 is important for intra-islet paracrine mechanisms in the communication of $a$ and $\beta$-cells ${ }^{[3]}$.

The hallmark in the pathology of classical type 1 diabetes is the $\beta$-cell destruction caused by a complex autoimmune process ${ }^{[11]}$. Environmental factors are suspected to be responsible, i.e. activating the immune system by reduction in gut microbiota, by early introduction to fruit or cow milk during childhood, by gluten, by toxins and especially by viruses ${ }^{[12]}$. Interestingly, besides inducing autoimmunity, some viruses like Enteroviruses might also exert direct cytolytic effects on pancreatic $\beta$-cell ${ }^{[13]}$.

The patient reported here presented several weeks after a viral infection with a severe DKA with a profound loss of $\beta$-cell function. However, in contrast to the general idea that viral infections indirectly affect pancreatic $\beta$-cells by triggering autoimmunity, the absence of five typical antibodies in our patient might argue against classical autoimmune type 1 diabetes. Given the fact that ACE2 is expressed on pancreatic $\beta$-cells and ACE2 is the main receptor for COVID-19 (Sars-CoV-2) internalization we would like to propose a direct cytolytic $\beta$-cell damage due to COVID-19 (Sars-CoV-2) resulting in an insulin-depended diabetes without a classical autoimmune pathology in our patient. This assumption is supported by a 
recent mechanistic study demonstrating that adult human pancreatic alpha and beta cells are permissive to Sars-CoV-2 pseudo-entry virus and Sars-CoV-2 virus infection ${ }^{[14]}$. Furthermore, Sars-CoV-2 infection of pancreatic endocrine cells resulted in robust chemokine induction as seen in Covid-19 patients and upregulation of markers of cell death ${ }^{[14]}$.

Despite a tremendous progress in biomedical research during the last centuries, the complex immunopathology of type 1 diabetes is still not elusively understood. A detailed understanding in the induction and progression of pancreatic $\beta$-cell failure, however, is crucial to develop novel innovative therapies to prevent and/or cure this important metabolic disease. In that regard, the detailed examination of patients developing $\beta$-cell failure and insulin-dependent diabetes after a COVID-19 infection in the future might yield novel insight into the yet unknown role of ACE2 in $\beta$-cell function and also possible virus induced cytolytic processes in type 1 diabetes development. Thus, a global registry

has been launched to provide a systematic platform for collecting and analyzing these patients ${ }^{[15]}$. It will be critical to explore the frequency, severity and duration of these complications and to explore more deeply the mechanisms in primary human tissue. However, giving the fact that five different antibodies were tested negative our findings clearly suggest that diabetologists need to be aware of the possibility of an insulin dependent diabetes as an acute complication in COVID-19 (Sars-CoV-2) infected patients.

\section{Research Design And Methods}

The patient reported here was treated at the Intensive Care Unit as well as the Division of Endocrinology, Diabetes and Clinical Nutrition at the Department of Medicine 1 at the University of Kiel, Germany. All authors were directly involved in the treatment of the patient. The patient provided written informed consent for the information presented in this Case Report to be published. Patient care and research were conducted in compliance with the Case Report guidelines and the Declaration of Helsinki.

Blood and urine samples (including autoantibodies against islet cells, GAD65, IA-2, insulin and ZnT8 in serum) were analyzed at the Department of Clinical Chemistry and Laboratory Medicine of the University of Kiel, Germany. Antibodies against COVID-19 (Sars-CoV-2) were determined by an external laboratory using the EDI ${ }^{\text {TM }}$ Novel Coronavirus COVID-19 IgG ELISA Kit (Epitope Diagnostics, San Diego, USA).

\section{Declarations}

\section{Acknowledgments:}

Author contributions: T.H. took cared of the patient on the ward and wrote the manuscript. D.M.S. took care of the patient in the emergency room and wrote the manuscript. A.G. took care of the patient on the intensive care unit and edited the manuscript, S.S. took care of the patient in the emergency room and wrote the manuscript. S.R.B. critically reviewed the case and wrote the manuscript. M.L. took care of the patient on the ward and wrote the manuscript.

\section{Statement of guarantor:}


Conflict-of-interest: Authors have no relevant conflict of interest to disclose.

\section{References}

[1] Hoffmann M, Kleine-Weber H, Schroeder S, Krüger N, Herrler T, Erichsen S, Schiergens TS, Herrler G, Wu $\mathrm{NH}$, Nitsche A, Müller MA, Drosten C, Pöhlmann S. SARS-CoV-2 Cell Entry Depends on ACE2 and TMPRSS2 and Is Blocked by a Clinically Proven Protease Inhibitor. Cell. 2020, 181:271-280.e8

[2] Xuan X, Gao F, Ma X, Huang C, Wang Y, Deng H, Wang S, Li W, Yuanet L, Activation of ACE2/angiotensin (1-7) attenuates pancreatic $\beta$ cell dedifferentiation in a high-fat-diet mouse model, Metabolism 2018, 81:83-96

[3] Roca-Ho H, Palau V, Gimeno J, Pascual J, Soler MJ, Riera M, Angiotensin-converting enzyme 2 influences pancreatic and renal function in diabetic mice, Lab Invest, 2020, doi.org/10.1038/s41374-0200440-5

[4] Shoemaker R, Yiannikouris F, Thatcher S, Cassis L: ACE2 deficiency reduces beta-cell mass and impairs beta-cell proliferation in obese C57BL/6 mice. Am J Physiol Endocrinol Metab, 2015, 309:E621631.

[5] Velavan, T., Meyer, C. The COVID-19 epidemic. Tropical medicine \& international health, 2020, 3:278280.

[6] Tay MZ, Poh CM, Renia L, MacAry PA, Ng LFP: The trinity of COVID-19: immunity, inflammation and intervention. Nat Rev Immunol. 2020 [epub ahead of print]. doi: 10.1038/s41577-020-0311-8

[7] Bornstein SR, Rubino F, Khunti K, Mingrone G, Hopkins D, Birkenfeld AL, Boehm B, Amiel S, Holt RIG, Skyler JS, DeVries JH, Renard E, Eckel RH, Zimmet P, Alberti KG, Vidal J, Geloneze B, Chan JC, Ji L, Ludwig B: Practical recommendations for the management of diabetes in patients with COVID-19. Lancet Diabetes Endocrinol. 2020, 8: 546-550. doi: 10.1016/S2213-8587(20)30152-2.

[8] Chee YJ, Huey Ng SJ, Yeoh E: Diabetic ketoacidosis precipitated by Covid-19 in a patient with newly diagnosed diabetes mellitus. Diabetes Res Clin Pract. 2020; 164: 108166. Published online 2020 Apr 24. doi: 10.1016/j.diabres.2020.108166

[9] Fleischer B. CD26: a surface protease involved in T-cell activation. Immunol Today. 1994, 15:180184.

[10] Letko M., Marzi A., Munster V. Functional assessment of cell entry and receptor usage for SARS-CoV2 and other lineage B betacoronaviruses. Nat Microbiol. 2020, 5:562-569.

[11] Saberzadeh-Ardestani B, Karamzadeh R, Basiri M, Hajizadeh-Saffar E, Farhadi A, Shapiro AMJ, Tahamtani Y, Baharvand H: Type 1 Diabetes Mellitus: Cellular and Molecular Pathophysiology at A Glance. Cell J, 2018, 20:294-301. 
[12] Knip M, Simell O: Environmental triggers of type 1 diabetes. Cold Spring Harb Perspect Med, 2012, 2:a007690.

[13]

Rodriguez-Calvo T, Sabouri S, Anquetil F, von Herrath MG: The viral paradigm in type 1 diabetes: Who are the main suspects? Autoimmun Rev, 2016, 15:964-969.

[14] Yang L, Han Y, Nilsson-Payant BE, Gupta V, Wang P, Duan X, Tang X, Zhu J, Zhao Z, Jaffré F, Tuo Zhang, Kim TW, Harschnitz O, Redmond D, Houghton S, Liu C, Naji A, Ciceri G, Guttikonda S, Bram Y, Nguyen DHT, Cioffi M, Chandar V, Hoagland DA, Huang Y, Xiang J, Wang H, Lyden D, Borczuk A, Chen HJ, Studer L, Pan FC, Ho DD, tenOever BR, Evans T, Schwartz RE, Chen S: A Human Pluripotent Stem Cellbased Platform to Study SARS-CoV-2 Tropism and Model Virus Infection in Human Cells and Organoids. Cell Stem Cell. doi: 10.1016/j.stem.2020.06.015

[15] Rubino F, Amiel SA, Zimmet P, Alberti G, Bornstein SR, Eckel RH, Mingrone G, Boehm B, Cooper ME, Chai Z, Del Prato S, Ji L, Hopkins D, Herman WH, Khunti K, Mbanya JC, Renard E: New-Onset Diabetes in Covid-19. N Engl J Med. 2020: NEJMc2018688. Published online 2020 Jun 12. doi: 10.1056/NEJMc2018688

\section{Tables}

Table 1 - Immune diagnostic

\begin{tabular}{|l|l|l|}
\hline & Result & Reference range \\
\hline GAD65-AA & $<5 \mathrm{IU} / \mathrm{mL}$ & $<10$ \\
\hline IA-2-AA & $<10 \mathrm{IU} / \mathrm{mL}$ & $<10$ \\
\hline IC-AA & negative & negative \\
\hline I-AA & $<0.1 \mathrm{IU} / \mathrm{mL}$ & $<0.4$ \\
\hline ZnT8-AA & $<10 \mathrm{IU} / \mathrm{mL}$ & $<15$ \\
\hline COVID-19 (Sars-Cov-2) IgG & positive & \\
\hline COVID-19 (Sars-Cov-2) IgM & negative & \\
\hline
\end{tabular}


I-AA, insulin autoantibodies; IC-AA, islet-cell autoantibodies; GAD65-AA, glutamic acid decarboxylase autoantibodies; IA-2-AA, tyrosine phosphatase autoantibodies; ZnT8-AA, zinc-transport-8 autoantibodies. 